\title{
Pitfalls and Promises for a Global Ethics
}

\author{
Paul F. Knitter \\ Xavier University, Cincinnati
}

With so many others, I am in deep, appreciative, and enthusiastic support of the proposals and search for a global ethic that Hans Küng and Leonard Swidler have been advancing over the past years (Küng 1991; Swidler 1992). The "Declaration of a Global Ethic" that was approved by 250 religious leaders at the World Parliament of Religions in Chicago on 4 September 1993 (Küng and Kuschel 1993) represents a goal that all peoples and all religions must resolutely move toward if they are to exercise "global responsibility" in resolving the crises that face our planet as it enters the twenty-first century. (For a careful but sobering description and analysis of these multiple crises, see Kennedy [1993].)

The critical remarks that follow are meant, in the fullest sense, to be a positive criticism-a support that will enable Küng, Swidler, and all of us to achieve this necessary goal of a global ethic that will ground a global responsibility. I fear that, unless the warnings and directions that I am suggesting are taken to heart, the path that Küng and Swidler are walking can either turn into a dead-end or, contrary to their intentions, lead to an end they are trying to avoid.

In order to achieve a global ethic, Küng and Swidler propose an openended, pluralistic dialogue among all the religions and ideologies of the world. They endorse a genuinely pluralistic approach to elaborating this ethic. While I certainly agree that such pluralistic dialogue is indispensable for the formulation and acceptance of a global ethic, I want to add that indispensable to the success of such a dialogue is a clear recognition that this kind of pluralistic dialogue is as dangerous as it is necessary. To succeed in their proposal, Küng and Swidler must be aware of these dangers. I fear that they are not.

\section{PITFALLS: THE DANGERS OF DOMINATION}

The dangers of a pluralistic dialogue toward a global ethic are pointed out by the critics who do a political-economic analysis of the world and of the political structures and agenda that influence all our knowing and all our 
academic as well as religious pursuits. Their central critique focuses on how easily a pluralistic dialogue that calls for the contributions of everyone can be, or has been, co-opted and used by the dominant power holders of the world in order to maintain their control. The trite but telling image used by one of these critics is the McDonald's hamburger. Although the "Big Mac" has served as a symbol of growing universality, literally present to and embracing all cultures, it is also, in the view of many, a manifestation of, and a delicious distraction from, an economic system that dominates and exploits the world. In the same way, the call to formulate a global ethics through pluralistic dialogue may appear as a noble affirmation of universality when, really, it is an instrument of the dominant economic power blocs. Kenneth Surin minces no words in unpacking the hamburger symbol:

The McDonald's hamburger is the first universal food, but the people -be they from LaPaz, Bombay, Cairo, or Brisbane-who eat the McDonald's hamburger also consume the American way of life with it. Equally, the adherents of the world ecumenism canvassed by the religious pluralists align themselves with a movement that is universal, but they too consume a certain way of life. ... To resist the cultural encroachment represented by the McDonald's hamburger, therefore, is of a piece with resisting the similar depredation constituted by the world ecumenism [i.e., by calls for global agreements on ethics]. (Surin 1989, p. 201)

The reason why Surin and others warn that calls for a pluralistic dialogue can be turned into "depredation" has to do with what we can term the political or ideological nature and intent of all language. Put simply, our language and our truth claims are not only culturally conditioned, but they are also economically and politically conditioned. They are rooted in our political or economic position in society and in our desire either to maintain that position or to better it. Our interpretations and our language, therefore, do not simply limit our own grasp of truth; they can also oppress the ability of others to assert and live their own truths. Language is not only limiting; it is also self-serving of one group and oppressive of others. David Tracy has taken these admonitions seriously: "Every discourse bears within itself the anonymous and repressed actuality of highly particular arrangements of power and knowledge. Every discourse, by operating under certain assumptions, necessarily excludes other assumptions. Above all, our discourses exclude those others who might disrupt the established hierarchies or challenge the prevailing hegemony of power" $(1987$, p. 79).

We might easily miss the deeper, all-pervasive content of what is here being recognized about language and interpretation. What we did not face in the immediate past (modernity) and what has become frighteningly clear today (one of the postmodern insights) is that such exclusion of others, 
such power-serving and self-serving acts, are not just an occasional "misuse" of language that can be removed much as one clears one's throat. Rather, we are speaking about "systemic distortions," pervasive tendencies within all use of language-a disease in our vocal cords! We cannot interpret and we cannot speak without hearing-and often responding to-the siren call of ideology, the inclination to use our "truth" for our own power or dominance: "Ideologies are unconscious but systemically functioning attitudes, values, and beliefs produced by and in the material conditions of all uses of language, all analyses of truth, and all claims to knowledge. . . . Ideologies are carried in and by the very language we use to know any reality at all" (Tracy 1987, p. 77). Thus, to understand the words that others, or we ourselves, are using, we have to ask questions about the ideologies that lurk within our language, ideologies that are rooted in our sociopolitical situatedness. I do not hear either Küng or Swidler asking those kind of questions.

Michael Foucault helps us appreciate more profoundly this political nature of language. We do not have to agree with him fully in order to learn from him. His basic claim is that truth is tied to power-that what society holds up to be normal or sane or good or noble is determined not by any objective pursuit of truth but rather by the power structures in the given society (Foucault 1980; Rabinow 1984). Toward the end of his life, Foucault seems to have modified his claims and admitted that knowledge and power cannot be equivalent (see Placher 1989, p. 103; cf. Foucault 1984 , p. 18); still, his central insight remains: we are always playing with power when we are making assertions about what is really true, praiseworthy, beneficial for all members of society. If we do not sufficiently take this into account, we can so easily turn what is truth for us into power and control over others.

And this is the warning that critics raise of programs for dialogue such as Küng and Swidler propose-that, because they are not sufficiently aware how all truth claims are political and "powerful," their program for a pluralistic dialogue toward a global ethic can become, whether they are aware of it or not, oppressive of others. This process of oppression works basically the same way it does in what is called civil discourse within or between nations; in fact, interreligious dialogue can all too easily be sucked into and made part of the oppression and manipulation that so often hides beneath the cloak of civil discourse. Behind all the pretty, inspiring words about the beauty of democracy and plurality, the necessity of dialogue, the value of everyone's voice, there is a process or program that sets the agenda in order to control, mollify, dilute, anyone whose voice might upset the status quo. Within the dialogue or civil discourse, the people in power remain in control. A traditional proverb makes the same point: "Every man for himself and God for all' said the elephant as he danced among the chickens" (Lindsey 1992, p. 50). 
Theologians like Küng and Swidler often seem to think that there is something like Adam Smith's "magic hand" guiding their calls for openended, all-inclusive dialogue and assuring that its results will benefit all; to forget the ever-intruding realities of economic, national, class, gender, and racial interests is as naive and dangerous within the interreligious dialogue as it is within the capitalist (or socialist) system: "Modernity contains demonic forces operating under the name of freedom; in the name of free discourse and pluralism, these forces may operate to impose a consensus that is actually domination of the many by the few" (Lindsey 1992, p. 67).

Therefore one must be aware, as First World theologians generally are not, that, whenever the language of civil discourse and religious dialogue comes forth from those who are in political or economic power, such language can all too easily be a ploy to maintain the structures of power. The discourse becomes "managerial"-it manages what will be discussed, the method for discussion, and the goals of the discussion; what does not fit these determinations is judged, in the political discourse, as a disruptive "interest group"; in the religious dialogue it might be called a closed or primitive or fundamentalist or polytheistic or feminist perspective.

Critics of literary theory help give voice and substance to these political warnings that all proponents of dialogue must take seriously. One might substitute interreligious dialogue for the last two words in the subtitle of Ellen Rooney's book Seductive Reasoning: Pluralism as Problematic of Contemporary Literary Theory. She reveals how "pluralism is the method employed by the central authorities to neutralize opposition by seeming to accept it" (Rooney 1989, p. 242). The strategy of pluralism, Rooney explains, is to exclude such interests as gender, race, class, sexual orientation, or national identity as peripheral to the process of interpreting a text or carrying on a conversation; rather, the process of pluralistic discourse calls on all interpreters to speak a "common language" or to adopt a basic methodology or to follow "right reason" rather than to introduce "interested rhetoric" or provincial concerns (see also Lindsey 1992, pp. 62-65).

Another literary theorist, Raymond Williams, sounds a warning that should be announced before every interreligious dialogue toward a global ethic: "A primary means by which privileged groups mask their hegemony is via a language of common contribution and co-operative shaping; to the extent that such groups can convince all partners in public dialogue that each voice contributes equally, to that extent does the conversation deflect attention from the unequal distribution of power underlying it" (Williams 1977, p. 112).

Here is where the critics press their case. People who advocate interreligious dialogue and programs for global consensus have not been sufficiently aware of the "unequal distribution of power" that underlies their discourse. So they can be (and have been) co-opted by these structures of power. Today we hear much talk about the "global village" in which we all 
must acknowledge and jointly exercise, in Hans Küng's terms, "global responsibility" based on a global ethic. In this effort, Küng proclaims the demise of Eurocentrism and the coming to be of a "post-colonial," "postcapitalist" economy that will be part of the aborning "multi-confessional ecumenical world society" (Küng 1991, pp. 19-20). Unity, peace, cooperation-these are the possibilities that are now within reach if we would only endorse and carry out this program of global discourse!

Yet here is where, because they are not doing their political-economic analysis, Küng and his followers can so easily be swallowed up and used by the powers that be. They are not aware, as Surin points out, that the Euro-/Western-centric powers of domination have not been dismantled; rather, they have been disguised. The stark, horrible inequalities between rich and poor, North and South, that continue to produce massive human and ecological suffering are still there; indeed, they are increasing rather than diminishing.

Why, in all their glowing language about cooperation and well-being, are the proponents of a global dialogue toward a global ethic not talking about this? More so, why are they not talking about the political and economic structures that continue to maintain and produce these inequalities? We are in not a postcolonial but a neocolonial world. The "new world order" is the old world order cleaned up, focused, given a new face (Nelson-Pallmeyer 1992). Theologians like Küng do not seem to recognize that "the rise and dominance of the West has been metamorphosed, or been 'sublated' into a 'new' project, that of the 'rise and dominance of the global' " (Surin 1989, p. 196). The "global" or "new world order" is being determined by those with the economic and military power.

And, because the proponents of global dialogue are not aware of these political realities, they can speak, as the global declaration does, "the language of the angels" and condemn the horrible evils of racism, poverty, sexism, ecological devastation; they can summon all religious believers to assume global responsibility and a new world ethic-but they do so without becoming too specific, without raising the uncomfortable questions that would challenge the basic structures of power and the economic system (and maybe their own jobs!). Surin is specific in this criticism: "European colonialism is condemned, but the neocolonialism into which it has been largely transmuted is again not positioned in their discourse. Thus David Livingstone and the East India Company will be rightly criticized, but not the United Fruit Company, or the Union Carbide Corporation or the International Monetary Fund or the World Bank" (Surin 1989, p. 207).

So, from the perspective of political analysis and awareness, good-intentioned theologians, if they are not careful, can become perpetrators or pawns of the oppression or mistreatment of others. So how can they be careful? 


\section{PROMISE: THE HERMENEUTICAL PRIVILEGE OF VICTIMS}

The first thing that a theologian like Küng or Swidler should do after sounding a call for a "global ethic" is to be suspicious of such a call. Again, I find little indication of such suspicion in the statements or declarations that they have proposed. Such suspicion or awareness is a necessary condition for being able to protect such projects from the worm of ideology that infects all our language, especially when we are making global or universal claims. We must be aware that the worm is endemic to our human condition; we must, from the start, be checking our proposals for infection. In the technical language of contemporary hermeneutics, we must begin, and then continue, our project for a global ethic with a strong dose of bermeneutical suspicion. We must be constantly vigilant and ready to face and ferret out where it is that our truth claims are power claims.

In confronting such a task, we are helpless by ourselves. Alone, we cannot be hermeneutically suspicious. Left to themselves, First World theologians like Küng and Swidler (and myself!) cannot carry out the constant diagnosis necessary to protect their projects from the worm of ideology. Here, precisely here, is where the voices of the oppressed must play a privileged role in the dialogue toward a global ethic: without their voices, we theologians and philosophers of the First World cannot carry out a hermeneutical suspicion of our own tradition or of our own contribution to the dialogue. By ourselves, we are self-serving selves. We need guides along the path to a global ethic.

Aloysius Pieris, who practices dialogue in the midst of Asia's suffering and oppression, tells us who these guides are: "The people who can truly purify a religion of communalist ideology are not the theologians or the religious hierarchs, but only the conscienticized victims of that ideology" (Pieris 1989, pp. 308-309). Only with the help of the oppressed can the oppressors truly face their own oppression.

John O'Brien articulates a growing awareness among Christian theologians that a hermeneutical privilege of the oppressed must be accorded a "relative normative status" in all theological method. The reason for this is not that the poor and the oppressed can claim any kind of a moral superiority or an exclusive grasp of reality; rather, their privilege is a "therapeutic" one-necessary to diagnose and remedy our ideological distortions. What O'Brien states about the "method of theology" must, I suggest, be affirmed about the "method of interreligious dialogue" to be used in the project for a global ethic: "Thus, the hermeneutical privilege of the option for the poor in theological method is not an ethical privilege, nor even an analytical one in terms of theory or praxis considered in themselves. Its privilege lies in the fact that it is the irreplaceable perspective from which theology can critically correct its methodological self-awareness. In essence, it does this by exercising a therapeutic role, whereby it 
creates conditions for theologians to come to an awareness of the practical roots of their models of discourse" (O'Brien 1992, p. 159; see generally pp. 150-161).

So, in their proposals for a dialogical global ethic, Küng and Swidler can and must defend themselves against the co-optation of dialogue by making sure that, in all the conversations and deliberations about a global ethic, the victims of the world-the poor and suffering and those speaking for the suffering earth-will be present and will have a privileged place in the conversations. In other words, we must recognize and insist not simply that "each voice contribute equally" but that some of us have a more urgent and a more helpful word to speak-namely, those who in the past have not spoken and who in the present are victims. If dialogue must always be par cum pari (equal with equal), there are also those who are primi inter pares (first among equals). In assigning a privileged role to the victims, we will have to move out from beneath the McDonald's arch (if for no other reason than that, in most Third World countries, the poor cannot afford a McDonald's hamburger).

But just what is meant by this bermeneutical privilege or priority for the voices of the voiceless? Certainly, I am not suggesting that theirs are the only voices to be heard. A central concern for overcoming oppression and suffering does not deny, indeed it demands, that our conversations and efforts be and remain plural. The voices of the affluent, of the middle class, of mystics and artists, must be heard together with the voices of the oppressed. Also, the priority and privilege given to victims does not mean that their views or claims are simply and always normative. Victims can also have distorted interpretations of their reality and dangerous plans to remedy it. There are no absolutely privileged seats, no final gavels, around the table of dialogue.

Rather, to assign a privileged place to victims means, I suggest, that no conversation can be considered complete or finished unless the voices of the suffering have been heard. Also, these voices must be heard, not only "first" (as David Tracy 1990 admits), but also "constantly" (Taylor 1990, p. 66) and seriously. To take them seriously, to be able really to listen to them, we will have to recognize that it will often be difficult to hear and to understand them and that we will have to overcome initial reactions of mistrust and avoidance. Speaking from his established place in academia, David Tracy has recognized this:

All the victims of our discourses and our history have begun to discover their own discourses in ways that our discourse finds difficult to hear, much less listen to. Their voices can seem strident and uncivil-in a word, other. And they are. We have all begun to sense the terror of that otherness. But only by beginning to listen to those other voices may we also begin to hear the otherness within our own 
discourse and within ourselves. What we might then begin to hear above our own chatter, are possibilities we have never dared to dream. (Tracy 1987, p. 79)

But, if the suffering and the victimized are truly to exercise a hermeneutical privilege in our dialogues, it will not be sufficient for those with the power simply to listen to them; we will also have to act with and for them. Understanding what the suffering are saying, grasping the structures of oppression that keep them in bondage and that afflict our planet, is not simply a matter of "theory." It can come only from praxis. Our present-day world demands that those who engage in dialogue engage in some kind of liberative praxis. Without such praxis, we will not be able to "hear" the voices of the privileged victims, and our dialogue will be distorted or coopted: "What is demanded... is an alternative practice, that is, gestures and acts of solidarity with movements that wrestle against those unjust structures. Such a practice would modify the consciousness of the participants and affect the reading of their own religious tradition.... A new practice [is] an indispensable dimension of the quest for theological truth" (Baum 1991, p. 13).

Such a "new practice" is also an indispensable dimension for anyone engaged in a dialogue toward a global ethic. It is not sufficient to invoke only "the experts." It is not sufficient to call for "working groups of scholars" or for a "Global Ethic Research Center," as Küng and Swidler do. It is also essential for each First World participant to be engaged, somehow and in some degree, in actively listening to, working for, struggling and suffering with, those who have been the victims of oppression as they seek to understand and transform the political, economic, and cultural structures that have dehumanized their life. Without such real-life communicative praxis, the proponents of a global ethic will not be able to protect their projects from becoming a hidden weapon of domination.

We must, therefore, continue on this path to a global ethic. But we must do so with an acute suspicion of its dangers and in humble listening to and cooperation with the victims of injustice. In the words of the Magnificat, our project for a global ethic can be carried out only if "the mighty are put down from their thrones and those of low degree are exalted" (Luke 1:52).

\section{REFERENCES}

Baum, Gregory. 1991. "Radical Pluralism and Liberation Theology." In Radical Pluralism and Truth: David Tracy and the Hermeneutics of Religion, ed. Werner C. Jeanrond and Jennifer L. Rike. New York: Crossroad.

Foucault, Michel. 1980. Power/Knowledge: Selected Interviews and Other Writings, 1972-1977. Translated by Colin Gordon et al. New York: Pantheon.

1984. "Le souci de la verité." Magazine littéraire, May, p. 18. 
Kennedy, Paul. 1993. Preparing for the Twenty-first Century. New York: Random House.

Küng, Hans. 1991. Global Responsibility: In Search of a New World Ethic. New York: Crossroad.

Küng, Hans, and Karl-Josef Kuschel, eds. 1993. A Global Ethic: The Declaration of the Parliament of the World Religions. New York: Continuum.

Lindsey, William D. 1992. "Public Theology as Civil Discourse: What Are We Talking About?" Horizons 19, no. 1:125-147.

Nelson-Pallmeyer, Jack. 1992. Brave New World Order. Maryknoll: Orbis.

O'Brien, John. 1992. Theology and the Option for the Poor. Theology and Life Series, vol. 22. Collegeville, Minn.: Liturgical Press.

Pieris, Aloysius. 1989. "Faith Communities and Communalism." East Asian Pastoral Review 3-4:294-310.

Placher, William C. 1989. Unapologetic Theology: A Christian Voice in a Pluralistic Conversation. Louisville: Westminster/John Knox.

Rabinow, Paul A. 1984. The Foucault Reader. New York: Pantheon.

Rooney, Ellen. 1989. Seductive Reasoning: Pluralism as the Problematic of Contemporary Literary Theory. Ithaca, N.Y.: Cornell University Press.

Surin, Kenneth. 1989. "A 'Politics of Speech': Religious Pluralism in the Age of the McDonald's Hamburger." In Christian Uniqueness Reconsidered: The Myth of Religious Pluralism, ed. Gavin D'Costa. Maryknoll: Orbis, pp. 192-212.

Swidler, Leonard. 1992. "Toward a Universal Declaration of a Global Ethic." Privately distributed.

Taylor, Mark Kline. 1990. Remembering Esperanza: A Cultural-Political Theology for North American Praxis. Maryknoll: Orbis.

Tracy, David. 1987. Plurality and Ambiguity: Hermeneutics, Religion, Hope. New York: Harper \& Row.

. 1990. Dialogue with the Other: The Inter-Religious Dialogue. Grand Rapids: Eerdmans.

Williams, Raymond. 1977. Marxism and Literature. New York: Oxford University Press. 